Cinémas

Revue d'études cinématographiques

Journal of Film Studies

\title{
Memory in Drag : Historical and Sexual Strategies in Tomás Gutiérrez Alea's Memories of Underdevelopment
}

\section{Bruce Williams}

Volume 8, numéro 3, printemps 1998

Cinélekta 2

URI : https://id.erudit.org/iderudit/024760ar

DOI : https://doi.org/10.7202/024760ar

Aller au sommaire du numéro

Éditeur(s)

Cinémas

ISSN

1181-6945 (imprimé)

1705-6500 (numérique)

Découvrir la revue

Citer cet article

Williams, B. (1998). Memory in Drag : Historical and Sexual Strategies in Tomás Gutiérrez Alea’s Memories of Underdevelopment. Cinémas, 8(3), 105-120.

https://doi.org/10.7202/024760ar
Résumé de l'article

Rendu un vrai fétiche de la stagnation par la mort du régime bourgeois à Cuba, le corps du protagoniste masculin des Mémoires du sous-développement de Tomás Gutiérrez Aléa permettent que le corps masculin se transforme en locus où les contradictions implicites dans les moments de transformation historique convergent et s'expriment librement. 


\title{
Memory in Drag: Historical and Sexual Strategies in Tomás Gutiérrez Alea's Memories of Underdevelopment
}

\section{Bruce Williams}

\begin{abstract}
RÉSUMÉ
Rendu un vrai fétiche de la stagnation par la mort du régime bourgeois à Cuba, le corps du protagoniste masculin des Mémoires du sous-développement de Tomás Gutiérrez Alea permettent que le corps masculin se transforme en locus où les contradictions implicites dans les moments de transformation historique convergent et s'expriment librement.
\end{abstract}

\section{ABSTRACT}

Rendered a true fetish of stagnation by the death of Cuba's bourgeois regime, the body of the male protagonist of Tomás Gutiérrez Alea's Memories of Underdevelopment becomes a locus onto which the sexual strategies of the film debunk the contradictions implicit in moments of historical change.

In "Revolutionary Consciousness and Imperfect Cinematic Forms," Katherine Singer Kovács explores the role of the creation of the ICAIC (the Instituto Cubano del Arte e Industria Cinematográficos) in Castro's multifaceted education campaign. Intended as a tool for transforming the values and attitudes left over from U.S. political and economic dominations, the ICAIC has served an ideological purpose in a post-revolutionary 
socio-political sphere. Singer argues that notwithstanding the ICAIC's official task, the films it has produced have been surprisingly devoid of the formulas of socialist art. Cuban films tend towards open-endedness and artistic experimentation, revealing the potential of the avant-garde within the context of proletariat struggle. Singer traces the development of film in revolutionary Cuba and demonstrates how ICAIC's early years were characterized by the production of newsreels, educational short subjects, historical reconstructions, etc. "In documentaries, Singer asserts, [filmmakers] sought to preserve their recent revolutionary experiences, to show the differences between the past and the present, and to articulate goals for the future." (p. 102) Yet this initial interest in documentation soon gave way to further experimentation and to the defiance of traditional prototypes of film genre. Following the initial phase in which virtually all ICAIC filmmakers worked in documentary, a hybrid form developed in which fictional characters " [...] participate in historical events or actors commingle with real people in villages and barrios." (p. 102) Tomás Gutiérrez Alea's Memories of Underdevelopment (Memorias del subdesarrollo, 1968) is such a hybrid film.

Through a complex intertwining of the personal and the historical, dramatized sequences and found footage, Gutiérrez Alea explores the importance of memory both at the level of the individual and that of the state. His film reveals the processes whereby recollections of subjugation are ingrained in Cuban consciousness. Most significantly Gutiérrez Alea deploys diverse narrative strategies through which the historical and the erotic converge, thereby allowing events of the early years of Revolutionary Cuba to be re-read through a transgressively sexual context.

In his introduction to a 1990 critical edition of the screenplay to Alea's film, Michael Chanan discusses the significance of the title of both the film and the 1962 novel by Edmundo Desnoes upon which it was based. Contrasting the Spanish title with that of the English release of the novel, Inconsolable Memories (a quotation from Alain Resnais' Hiroshima, mon amour), Chanan stresses that the original title positions the text on the turf of the historical 


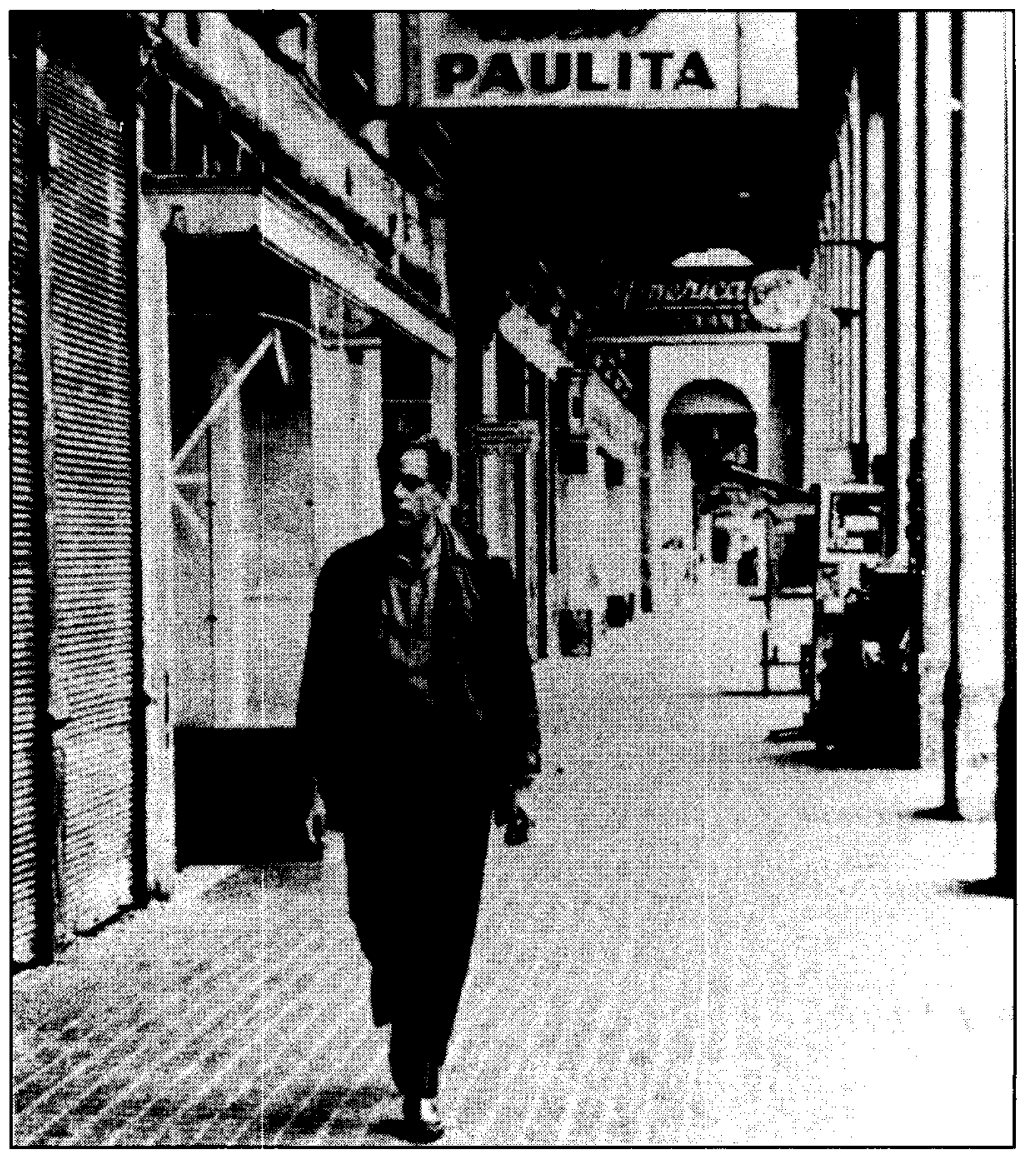

\section{Memorias del subdesarrollo de Tomás Gutiérrez Alea (1968)}

rather than the subjective, referring specifically to the postcolonial context of revolutionary Cuba. Defining underdevelopment as " $[\ldots]$ the relationship between a country and the metropolis that colonizes it," (p. 3), Chanan foregrounds the irony implicit in the title, "[...] for what the film shows is the way that people continue to carry the mentality of underdevelopment within them, how it weighs them down, and how it becomes a problem." (p. 3) For both Gutiérrez Alea and Desnoes the theme of memory is indeed of prime importance. Yet Chanan fails to articulate the evocative potential of the novel's English title. 
Both novel and film draw explicitly upon the historical context of the cinema as well as that of Cuba itself. As the title Inconsolable Memories suggests, they allude specifically to Resnais' film which resonates with images of an actualized holocaust whose reprise the protagonist, Cuba and the superpowers feared in 1962. Recalling his second viewing of Hiroshima, mon amour, the novel's narrator, Sergio, acknowledges having turned his head so as not to view the roasted and paralyzed victims of the atomic blast. Emmanuelle Riva's line "J'ai desiré avoir une inconsolable mémoire" resonates for him as indicative that civilization (and eroticism) are predicated upon memory. Although Gutiérrez Alea's shooting script for Memories calls for inserts from Resnais' film, such specific intertextual references failed to find their way into the finished product. Yet Hiroshima nonetheless is evoked early on in the film by the presence of a cinema billboard which suggests the impact of the early moments of the French New Wave on Cuba and on Latin America in general. One need only recall the often "castrating" effect on Cinema nôvo of European mise en scène and of the desire of Brazilian filmmakers to gain " $[. .$.$] entry into a cinematic pantheon$ which begins with Eisenstein and extends to Godard and Straub." (Chanan, 1990, p. 47)

The reference made by both Desnoes and Gutiérrez Alea to Resnais' film surpasses a simple exploration of memory in the historical context. In the opening image of Hiroshima a couple makes love as a woman's voice evokes memories she desires to have of an atomic blast she has not witnessed lest it fade into oblivion. Memory and forgetfulness are eroticized and become interwoven into the film's complex sexual strategies. For Resnais the personal and the erotic are thus offered in response to the historical and apocalyptic. A similar process develops in Desnoes' novel, but with the eroticism removed from the ardent embrace of lovers and restricted to the domain of fetishism. Such fetishism serves to underscore the protagonist's sense of entrapment between two worlds. Furthering the process, Gutiérrez Alea's visual interpretation of Inconsolable Memories' sexual dynamics becomes increasingly transgressive and iconographically portrays the contradictions of a historical moment. Unlike 
Hiroshima in which historical processes are eroticized through the intimacy of intercourse, Memories of Underdevelopment proffers a visual fetishization of fragmented and dissociated historical images, mediated by the protagonist's personal story of alienation.

Deborah Glassman's elucidating analysis of Resnais' film provides further insights into the relationship between history and the visual image which are equally applicable to Memories of Underdevelopment. Discussing the voice-over dialogue between the lovers of the former film, Glassman stresses that for the female, all claims to having "seen" the blast at Hiroshima stem from secondary visual stimuli such as displays at the city's museum (photographs of burning and dying Japanese, displays of detached human hair, a melted bicycle, etc.). "The Durasian heroine typically affirms the power of images to preserve events and disparages the power of language to do so." (p. 32) As Glassman points out, Resnais' "Elle" attests to the documentary power of the visual. Describing the reaction of tourists visiting Hiroshima's museum, she avows: "The illusion is so perfect that the tourists cry... I have seen the newsreels. On the second day, history tells us, I did not make it up... I saw them. I saw the newsreels. I saw them." "You saw nothing," responds her Japanese lover. "Nothing." Glassman argues:

If Elle believes in visual representation, the male protagonist affirms the power of language. Their argument tums on the possibility of representation. If the trauma of Hiroshima can be equated with Elle's trauma, as one reading of the title suggests it can be, much is lost as history is written. This film takes narration to inscribe its own history as loss even as it supplants an event and a memory. Whether narration offers a cure from the malady of obsessional memory seems ambiguous. For it provides an exit for Elle from Nevers, the exit's the poorer for the tale. (p. 33)

Like Resnais' Elle, Gutiérrez Alea’s Sergio is also plagued by obsessive memories inscribed through the film through found footage and still photographs. Yet unlike the female protagonist of Hiroshima he distances himself from the images at hand 
through his "own" voice-over mediation, thus allowing his commentary to partially disavow the immediacy of the visual, to neutralize its impact, and to grant himself the safe haven of the fetish. In this respect, by introducing a counterpoint absent in Desnoes' novel, Gutiérrez Alea positions his protagonist (and the spectator) on turf considerably distinct from that occupied by the literary narrator of Inconsolable Memories.

The novel deploys a politicization of sexuality in which gender differences and erotic subjectivity are linked to complex issues of social transformation during the initial phase of the $\mathrm{Cu}$ ban revolution. Narrated from the point of view of a displaced bourgeois intellectual unable to come to grips with the postrevolutionary world view, Inconsolable Memories debunks the protagonist's pervasive sexism and queries his condemnation of Caribbean underdevelopment. Such a view, often misconstrued by the North American reader to imply a general denouncement of the Revolution, turns back upon itself, decrying underdevelopment as a direct result of the cultural colonialism to which Cuba was subjected initially by Spain and later by the United States. And the complicity of Desnoes' protagonist in this colonialism is indicted. Sergio Malabre links the female body and the lack of sophistication of Cuban women to his own ambivalent relationship with the commodity fetishes of the old order. Textualizing his personal strategies of disavowal implied by the fetish, he reveals a dubious mechanism for survival in a world in which he himself has been rendered a dinosaur.

Five years following the publication of Desnoes' novel, Gutiérrez Alea's film furthers Sergio's fetishization strategies by offering in counterpoint to the protagonist's subjective meanderings a complex intertextual collage of found and "pseudofound" footage. Newsreels, interviews and constructed ersatz documentary segments comment on the historical moment of stasis in which Cuba finds itself a pawn in the struggle between superpowers. Such footage not only foregrounds key episodes from the Bay of Pigs invasion and the U.S. reaction to the deployment of Soviet missiles on Cuban soil, but moreover, it attests to historical developments and transformations in Cuban film during the first decade following the creation of the ICAIC. 
Yet of equal significance to the manner in which Gutiérrez Alea proffers an audio-visual response to Sergio's disavowal is the transgressive manner in which the protagonist's fetishization is depicted. In the novel Desnoes describes in detail Sergio's fondling of his wife's personal effects following her departure to the United States and foregrounds the hero's fixation on lipstick and undergarments. Translating this into cinematic terms, Gutiérrez Alea intersects with the notion of fetishization a subversive component of low-drag. The image of Sergio sporting his wife's finery has become synonymous with the film and provides its most frequently reproduced production still. Like Desnoes' Malabre, Sergio fondles his wife's stockpile of femininity. Yet unlike his literary counterpart, he dons a fur stole, gazes at his own image in a mirror, and scratches a caricature of his wife on the glass, which is superimposed over his own mirror image. One can argue that in this image a masquerade of femininity converges with one of hyper masculinity. Sergio's white undershirt, clearly visible from under the stole recalls the fetishized male of the Hollywood cinema. Low-drag in the sense that there is no attempt to veil Sergio's maleness by the feminine finery, Gutiérrez Alea's transgressive genderfuck positions Sergio on ambivalent turf between the bourgeois constructs of masculinity and femininity which permeate his own world view and which suggest the contradictions plaguing him on a socio-political sphere. Visually responding to Desnoes' sexual strategies, Gutiérrez Alea thus further foregrounds Sergio's ambivalence in a world in transition, where vestiges of the old order merge with revolutionary fervor.

The sequence continues as Sergio drops the garment, retrieves a nylon stocking from a drawer, and pulls it over his head, distorting his features. Once again the image is highly textured. Sergio's mask positions him at once as perpetrator and hostage. Captive of the bourgeois finery he has fetishized, the protagonist draws upon the same arsenal in strategic assault upon social transformation. Sergio's position towards the revolution is ambivalent, as exemplified later in the film by a voiceover which decries bourgeois mediocrity. "Although it may destroy me, Sergio comments, this revolution is my revenge 
against the stupid Cuban bourgeoisie... It's my own life, everything I don't want to be. I remain lucid. It's a disagreeable lucidity, empty. I know what's happening to me but I can't avoid it."

Sergio's ambivalence towards the revolution is foregrounded in both the novel and film by the slippery essence of his fetishized objects, which oscillate between the commodity fetish and Freudian strategies for disavowal. Yet the specifically sexual dynamics of both works align the fetish much more closely to the latter. Laura Mulvey reminds us that one of the primary traits of the commodity fetish is an erasure of its own mechanics of production and its ability to emerge upon the marketplace as a "[...] self-generated object of fascination." (p. 12) Yet she stresses that the aesthetics of fetishism " $[\ldots]$ derive from the Freudian model ('I know very well, but all the same...'), which creates an oscillation between what is seen and what threatens to erupt into knowledge." (p. 19) Sergio's fetishism lies on the fringes of Freudian discourse in that it draws upon a fort / da mechanics of absence / presence more than upon a disavowal of sexual difference. The fetish allows the protagonist in Laura Mulvey's words "have his cake and eat it too," to acknowledge the departure both of Laura and of the old order while basking in the presence of the same. In Desnoes' novel, Sergio's evocation of the eighteen shades of lipstick Laura has left behind recalls his wife's fear that prior to her departure there was a growing shortage of consumer goods in Havana. Yet the narrator reminds us that Laura was actually made of the things she owned and wore, her feminine accessories becoming as much a part of her as her own body. For Desnoes' Sergio, however, the complexity of the fetish is compounded. Lipstick is equated with obscenity, and his vague recollection that Laura's lipstick color would change in accordance with the time of day and her dress becomes one of many disavowal mechanisms for coping with her absence. Sergio further evokes an adolescent relationship in which the taste and texture of lipstick excited him more than anything else. He would almost become aroused simply by noting the red marks on his handkerchief.

Desnoes' novel is replete with many other such references to fetishism. Suggesting that Cuban women never avoid eye con- 
tact, Sergio explores the relationship the dynamics of the male gaze in what he perceives to be the context of the Caribbean. The gaze becomes directly linked to his own disdain for Cuban culture and for the inconsistency of the country's women. Referring to a contemptuous remark made by a friend on a beach that the women passing by had bellies full of black beans (a comment which occurs as well in Gutiérrez Alea's film), Sergio affirms that such a thought has dealt a deadly blow to his concept of romantic love. Had the bellies been full of pheasant, soufflé, or even strawberry Jell-O, the hero's Weltanschauung would not have been destroyed. The gaze of Desnoes' protagonist is thus a phallic one, penetrating its object, dissecting and fragmenting it, and asserting the posture of superiority from which Sergio observes the world. In Desnoes' novel, the primacy of the gaze is implicit, yet it does not preclude other non-visual vehicles for fetishization. Sergio invokes the taste of his lover's kisses, the smell of soap and cheap perfume which aroused him in during adolescent visits to a prostitute, etc. The peculiar ambivalence of such strategies is foregrounded for they lead to a play of distance / immediacy. Sergio can separate himself from desire through an almost scientific observation and fragmentation. Yet the fetish evokes the past, allowing the protagonist a chimera of immediacy, of continuity of a past now dead.

In Gutiérrez Alea's film the inherent relationship between film and fetishism is played out not only on the level of Sergio's personal alienation, but also on that of documentary segments interwoven as integral to the text. In Divine Decadence, Linda Mizejewski has reminded us of the primacy of the camera's gaze which directs the spectatorial gaze within historical, psychoanalytical, and intertextual dynamics. The camera's gaze is more restrictive than that of the theatre, and Mizejewski argues that it " [...] can fetishize by what it discloses as well as by what it chooses to hide." (p. 120). In an oscillation between purely subjective shots (with the camera becoming conflated with Sergio's point of view), and intimate documentation of Sergio's activities and observations, Gutiérrez Alea's camera highlights, isolates, and crops objects and body parts to foreground the protagonist's sexual disavowal. Sergio's eye pierces through Laura's monocle 
with the same phallic measure of her lipstick as it is extracted from or retracted into the tube. Yet what is absent is of equal, if not greater consequence than what is overtly fetishized. If fetishism by nature implies a play of absence and presence, then such dynamics unfold in Memories of Underdevelopment at the site of the protagonist himself. Sergio is a primal presence in the film as he gazes at daily life in Havana's Vedado district through his telescope or mediates through voice-over the tumultuous events of the Bay of Pigs or the Missile Crisis. And it is perhaps when he disappears that he is most felt. Several segments of the film are photographed as if they were newsreel or documentary, and these mediate between Sergio's subjective meanderings and the archive film and television footage used to explore the historical context of a Cuba in transition. When he is absent from the camera's gaze we are painfully aware that the views of Havana, which Sergio derisively terms the "Tegucigalpa of the Caribbean," are actually mediated by the protagonist. Reminiscent of the documentary, these segments allow Sergio himself to be at once present and absent, his role as unreliable narrator even more forcefully indicted by the superficial impression of objectivity Gutiérrez Alea's visual style permits.

The absence / presence of Sergio as a mediating voice in Gutiérrez Alea's process of visual fetishism returns us to Katherine Singer Kovács' discussions of genre in the context of postrevolutionary Cuban cinema. The opening sequences of Memories of Underdevelopment follow suit with Kovács' conception of the "pseudo-documentary." The pre-title sequence depicts a carnival celebration in a manner typical of the ethnographic documentary. A slippage from the non-fiction realm to that of drama occurs when a gun fires and a man falls to the ground. Gutiérrez Alea thus intimates through the structure of the (seemingly isolated) segment that the film which follows will likewise fuse documentary and fiction. When the opening sequence is repeated towards the end of the film with protagonist Sergio witnessing the shooting as a neutral, disinterested spectator, the fusion of the two modes of discourse is complete. Sergio is inscribed into the documentary, into history, although he remains a character with very little agency. 


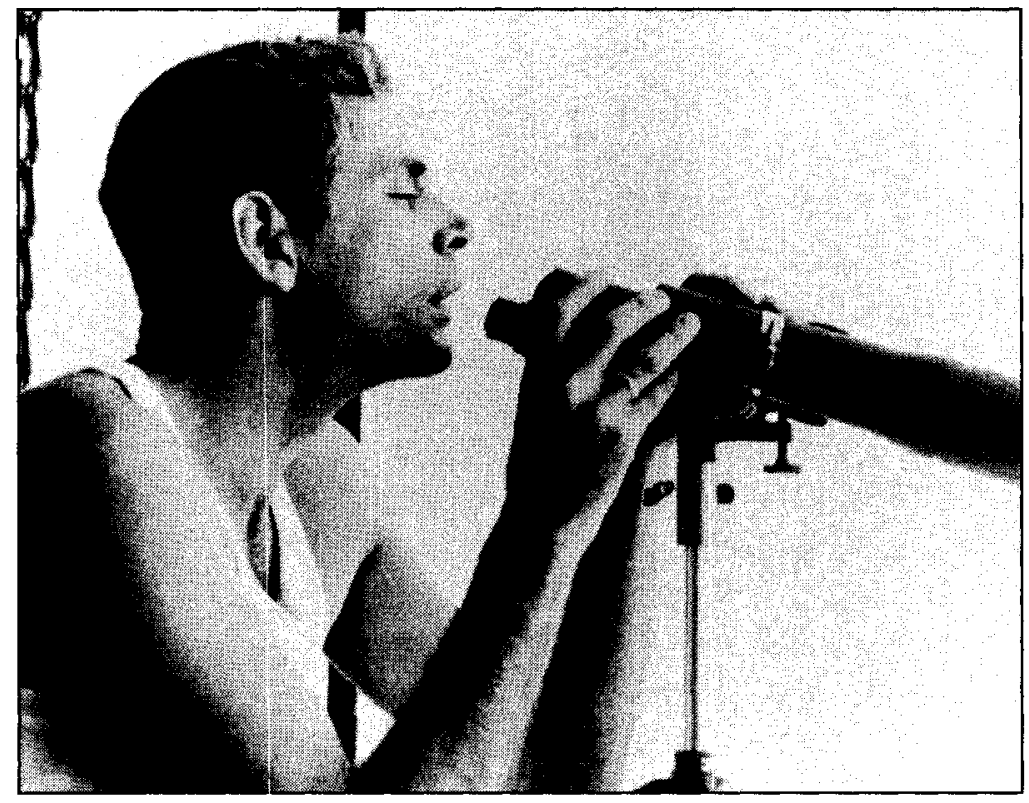

\section{Corrieri dans Memorias del subdesarrolo de Tomás Gutiérrez Alea (1968)}

Memories' second sequence likewise appears to follow in a non-fiction vein. Titles announce the time and situation: "Havana, 1961. Many People Are Leaving the Country." The camera documents the grief-ridden faces of Cubans as they bid farewell to their loved ones at Havana's José Martí Airport. Particular attention is slowly drawn to a man's goodbye to an elderly couple and a woman. The camera then follows the man as he boards a bus back to Havana. The narration thus slips from the documentary to the fictional as the voice-over commentary (obviously the man we have just seen) speculates as to the difficulties the woman will encounter in the United States. The viewer thus surmises that the man has just seen his wife and parents off to Miami, yet for whatever reason has opted to remain behind.

On its way from the airport to Havana, the bus passes a propaganda billboard alluding to the Bay of Pigs and the Cuban victory, thus situating the diegesis into a more specific historical moment. A cut to the protagonist's apartment further substan- 
tiates the temporal context with a point-of-view shot following the man through an stylish dwelling typical not only of the furnishings of the early Sixties, but moreover reflective of highly Europeanized tastes. We learn through the voice-over that the protagonist is a writer, yet his own ideology is not yet clear. The fusion of documentary and fiction is once again evoked by the man's voice-over allusion that he would write either a book of short stories or a diary if he had time. Equal importance is thus devoted to both fiction and testimony, and any distinction between the two seems of virtually no consequence to the protagonist.

The man then proceeds to a balcony overlooking Havana's chic Vedado district. He gazes at the cityscape through a telescope, fragmenting the panorama in a manner similar to that in which his own gaze will later crop and fetishize the female body. At this moment, he becomes not only a voyeur, scrutinizing his world from the safety of his high-rise balcony, but moreover, a voyeur contemplating a "historical moment." For him, Havana "[...] looks like a set, like a cardboard city." He comments upon the absence of both the imperial eagle atop the bronze Titan and of Picasso's promised peace dove. His references to Picasso as a "Communist millionaire in Paris" are virtually selfreflexive. We will soon learn that Sergio himself is caught between two distinct visions of the world, unable to discard his bourgeois lifestyle, yet unwilling to flee from the Revolution. Again, the moment is inscribed into the specific historical moment through subtle visual clues. Sergio's telescope catches sight of a torpedo boat in the harbor which, like the earlier billboard, reminds us that the Bay of Pigs invasion is a fresh historical event.

While Sergio's telescope ogles at Havana and at history, his own gaze fragments the female form. Gutiérrez Alea's protagonist, like his literary counterpart, asserts that Cuban women want to be "touched" by a man's gaze, yet insists that at an undefined point between thirty and thirty-five, the Cuban female body begins to rot. His disparaging remarks follow a general comment that human beings are basically exhibitionists and are intercut with an insert of Marilyn Monroe on a television screen. 
Cuban women are thus juxtaposed with the North American ideal, and their complete physical decadence by age thirty-five is underscored by the viewer's knowledge that Monroe herself died at age thirty-six. (The allusion to the North American actress recalls a poem by Ernesto Cardenal, "Oración por Marilyn Monroe" familiar to all educated Cuban viewers.) Monroe also evokes a specific historical moment. Although her death occurred a year after the departure of Sergio's wife for Havana, it was a significant moment for U.S. popular culture between the Bay of Pigs and the Missile Crisis. Moreover, her image becomes one of the fetishes of bourgeois cultural imperialism vis-à-vis which Sergio maintains such an ambivalent stance.

Sergio's belittling attitude to Cuba and his compatriots is particularly felt during his idle promenades through Havana and his documentary-like gaze at its inhabitants. The first such sequence is prefaced by an insert of the fire which destroyed the city's El Encanto department store. One must stress that Gutiérrez Alea follows approximate chronological order in his deployment of found footage within the film. Such footage and still photographs depict the course of history from the El Encanto fire and the Bay of Pigs to the anxiety-ridden moments of the Missile Crisis, as evoked by speeches by Castro and Kennedy. For Sergio, what was once the "Paris of the Caribbean" is now the "Tegucigalpa of the Caribbean," and the destruction of Havana's most famed department store was a key moment in that transition. As Sergio walks through the streets of his native city, his disdainful comments are juxtaposed with music reminiscent of the baroque, underscoring his own alliance with European culture.

Discussions of Cuba's precarious position between the superpowers is juxtaposed by Sergio's walk past a cinema in which Hiroshima mon amour is playing. Not only does the reference suggest worldwicle fear of a nuclear apocalypse, but moreover, it recalls the colonializing impact of foreign cultures on the island country. Sergio alludes to the problem of hunger and infant mortality in Latin America, yet his stance is one of distance. As his voice mediates still photographs of starving children, the images are fetishized and divested of their impact upon the

Memory in Drag: Historical and Sexual Strategies in 'Iomás Gutiérrez Alea’s... 
film's bourgeois protagonist. For the viewer, on the other hand, such a narrative strategy has quite the opposite effect. The photos become all the more powerful as the gap between social reality and Sergio's illusions increases. In a sequence which follows shortly thereafter, an insert of events from the trial of the Bay of Pigs prisoners is juxtaposed with images of a formal party with society matrons in elegant ball dresses. The contrast betrays Sergio's own precarious ideological position between the two worlds. Aware of the atrocities of the former regime and of the disregard of the upper crust for the crimes of "contract murderers, "Sergio reminds us of those who "[...] are not directly involved with death and who want to display their clean souls." Yet it is clear contextually that he will never align himself irrevocably with the revolutionary cause.

The film's first allusions to the ICAIC occurs as an insert of televised coverage of provocations by American soldiers at Guantanamo is introduced. A voice-over intimates espionage as a U.S. Marine flips the cameraman off. Such referentiality sets the stage for Sergio's own visit to the ICAIC with Elena, a would-be actress whom he meets on a Havana street, introduces to Gutiérrez Alea himself, and later seduces. When Sergio first spies Elena, his gaze crops her body and his first words to her are equally fetishizing. "You have nice knees," he declares. The young woman comments that she wants to be an actress because she is tired of always being the same and wants to unfold her personality. Sergio reminds her that all characters in theatre and film are like broken records; the only thing an actress does is repeat over and over the same gestures and words. We then cut to a loop of erotic sequences, each repeated several times: a man rolling on top of a woman, a naked woman stepping into a shower, a woman removing her panties, a striptease, and Brigitte Bardot yielding to a seducer. Yet another cut brings us to a screening room. Sergio and Elena are now sitting with Tomás Gutiérrez Alea watching these sequences which had been censored under Batista. The director stresses that he will use them in a collage film (obviously Memories of Underdevelopment). Sergio argues that the film must have meaning, but Gutiérrez Alea replies that "it is coming along." 
The censored inserts suggest the relationship the film develops between the erotic and the historical. Removed from the context of the source films and strung together as isolated images, they recall the process whereby newsreel footage and still photographs are recouped as a part of Sergio's personal narration. Gutiérrez Alea's reference that his collage film will consist of such footage accentuates the equation developed on the visual level between eroticism and historical images. The erotic loops fetishize and fragment as does Sergio's gaze both at women and at a particular historical moment in Cuban history. The oscillation between what is seen and what threatens to erupt into knowledge refers as much to those remnants of the old order that emerge through the cracks of the new Cuba as it does to Sergio's own position as a doomed species. Aware of the socioeconomic realities which have generated the Revolution and acutely attune to the cultural colonialism of Spain, the U.S., and now the Soviet Union, Sergio nonetheless must disavow the threat of complete and irrevocable social change. We are reminded that the protagonist's disavowal extends from his ambivalent recoupment of youthful loves to his irresolute stance $v i s-\grave{a}-v i s$ the historical moment. If Gutiérrez Alea's film implies a critique of revolutionary Cuba as the North American viewer often surmises, then its critique is that of residual social fetishism, of those who like Sergio must "have their cake and ear it too."

Yet it is neither archival footage nor the ersatz documentary segments which are most readily associated in the minds of both spectators and critics with Gutiérrez Alea's film. We must turn once again to the transgressive image of Sergio clad in Laura's stole scratching a lipstick caricature of feminine masquerade across his own image. Unlike Sergio's fetishized objects, this grotesque image does not disavow either sexual lack or historical transformation. Rather it presents a visual synthesis of the inherent contradictions both of Desnoes' Sergio Malabre and of his cinematic counterpart. Metonymically associating his own body with relics of the old order, Sergio perhaps unknowingly asserts his own role as fetish. The complex sexual strategies which have offered him a haven in the wake of personal loss 
now turn back upon themselves. Sergio dons his memories, but these are indeed memories of underdevelopment. Gutiérrez Alea's image is transgressive mostly because of its failure to disguise or mask. Six years following the publication of Desnoes' novel, its low-drag portrayal which would be comic in other circumstances bespeaks an inherent conflict of Cuba in 1968. The yoke of underdevelopment cannot be shed as long as society carries vestiges of its mentality. Sergio's hyper-masculinity and the feminine finery which accentuates rather than eradicates it are both remnants of the same underdevelopment. And Gutiérrez Alea fetishizes his protagonist, transforming him into a locus where the contradictions implicit in moments of historical transformation are permitted free expression. When reinterpreted cinematographically, the sexual strategy of Desnoes' text engenders visual icons and debunks the ideological disparities of the world whose demise has rendered the protagonist a fetish of stagnation.

The William Paterson College of New Jersey

WORKS CITED

Apter, Emily and William Pietz (eds.). Fetishism as Cultural Discourse. Ithaca: Cornell, 1993.

Chanan, Michael. The Cuban Image. Bloomington: Indiana, 1985.

Chanan, Michael. "Lessons of Experience," in Michael Chanan (cd.), Memories of Underdevelopment. New Brunswick: Rutgers (1990).

Garber, Marjorie. Vested Interests: Cross-Dressing and Cultural Anxiety. New York: Routledge, 1992.

Glassman, Deborah. "The Feminine Subject as History Writer." Enclitic, vol. 5, n"1 (1981), p. 43-53.

Johnson, Randal and Robert Stam (eds.). Brazilian Cinema. New Brunswick: Associated University Presses, 1982.

Kovács, Katherine. "Revolutionary Consciousness and Imperfect Cinema Forms." Humanities in Society, vol. 4, n"1 (1981), p. 101-112.

Mizejewski, Linda. Divine Decadence. Princeton : Princeton University, 1992.

Mulvey, Laura. "Some Thoughts on Theories of Fetishism in the Context of Contemporary Culture." October, n" 65 (1993), p. 3-20. 